\title{
Chest tubes in COVID-19 times: a safe way to protect the team
}

\section{SUMMARY}

INTRODUCTION: What has been published so far regarding safe methods to deal with chest tube insertion during COVID-19.

METHODS: A descriptive study of the literature available in the Medline/PubMed, Lilacs, Scopus databases and specialized books. The search was carried out using the terms "infectious diseases"; "COVID-19"; "Chest tubes".

RESULTS: This paper aggregates and consolidates some old concepts to new tactics to minimize the contamination of teams who deal with chest tubes, before, during, and after the procedure.

CONCLUSIONS: Health officials are under increasing pressure to control the spread of COVID-19, which is a very virulent disease. Our analysis brought together old rules against contamination along with new tactics for professionals who deal with chest drains in order to minimize the contamination of teams during the Pandemic.

KEYWORDS: Communicable Diseases. Coronavirus Infections. Chest tubes.

\section{INTRODUCTION}

So far, 1,086,990 cases of the new coronavirus have been recorded in Brasil, with 50,659 deaths in the entire territory ${ }^{1}$. As in other parts of the world, there is great concern about the contamination of health professionals who are dealing daily with suspected and confirmed patients of this new disease.

In China, the initial epicenter of the disease, more than 3,300 cases were reported among health professionals and about 22 deaths ${ }^{2}$.

Only among nursing professionals, 30 deaths were registered and another 4,000 had to be removed from work due to COVID-19, by April 2020 in Brasil ${ }^{3}$.

The SARS COV-2 that leads to COVID-19 has already been shown to be viable in aerosols and transmitted through droplets ${ }^{4}$.
Chest tube insertion is one of the most common procedures performed in trauma hospitals, Intensive Care Units, and elective surgery services, not only by surgeons but also by Clinicians and Emergency Doctors.

It is a procedure with great potential for generating aerosol during the procedure and the convalescence of the disease that generated the indication for drainage, especially in patients with continuous aerial escape ${ }^{5}$.

The purpose of this document is to list some maneuvers and precautions that can minimize the contamination of the team during the management of chest drains in this Pandemic. 


\section{METHODS}

A descriptive study of the literature available in the Medline/PubMed, Lilacs, Scopus databases and specialized books. The search was carried out using the terms "infectious diseases"; "COVID-19"; "Chest tubes". Our study brings what is known about the coronavirus and ways to protect teams dealing with chest tubes. This can assist hospitals in the next steps that can be taken to protect health professionals. This is a review article that brings information collected from different articles published since the beginning of the 2019 novel coronavirus epidemic.

\section{RESULTS}

\section{Before the procedure}

All materials needed to perform the procedure must be prepared before surgery. Some authors suggest the preparation of a BAG with all items to minimize the circulation of professionals between safe and contaminated areas.

The use of a HEPA or HME F filter, similar to the one recommended for orotracheal intubation ${ }^{6}$ should be considered and connected to the vent of the collecting bottle interposed by a cut orotracheal tube, in order to reduce possible contamination of the environment in collecting bottle with two vents, one of this must be isolated. (Figure 1).

It has already been demonstrated in the laboratory that the use of an antiviral filter reduces the emission of aerosols when coupled to the collector flask, thus reducing the chances of contamination by the team ${ }^{7}$.

The collection bottle mentioned here is a simple one, which works as a collector and water seal with two vents, widely used in hospitals of the Brazilian Unified Health System and other parts of the world (Figure 2).

It is recommended that the chest drain previously chosen for this purpose is already connected to the extension tube, to avoid an inadvertent exit from collections that may contaminate the team ${ }^{8}$.

Some authors recommend that the distal $1 / 3$ of the drain be clamped with a strong hemostat with the same purpose described ${ }^{8}$.

Preemptive multimodal analgesia with analgesic, non-steroidal anti-inflammatory, and an opiate in awake patients to reduce the pain of the procedure and reflexes that lead to the discharge of secretions that may serve as contaminants ${ }^{8}$.

In patients on mechanical ventilation, a neuromuscular blocker can be used as an additive to sedation to prevent coughing and viral contamination.

\section{During the procedure}

The recommended technique surgical chest tube insertion, the same recommended by the American College of Surgeons ${ }^{9}$.

The number of people at the bedside should be kept to a minimum, as in other procedures during the Pandemic, and should include the doctor who will perform the procedure, an assistant (who may be a more senior resident), and someone to open and deliver materials, such as a nurse ${ }^{10}$.

The physician responsible for the procedure must be the most experienced, and the presence of students or interns must be avoided to minimize the risk of contamination ${ }^{10}$.

All Personal Protective Equipment (PPE) available must be used for procedures that may generate aerosols: sterile and liquid-impervious apron, double gloves, Face Shield, Mask N95/PFF2, or higher ${ }^{11,12}$.

Wide skin antisepsis on the side to be drained, placement of sterile fields.

Full local anesthesia with $20 \mathrm{ml}$ of $1 \%$ lidocaine.

Small incision 2 to $3 \mathrm{~cm}$;

Drain passage in superior and posterior direction;

Making stitches around the drain for the wound to be tightly closed thus avoiding the discharge of secretions;

For those who use the drainage technique with closed hemostatic forceps on the distal $1 / 3$ of the drain, this should only be released when the drain has been connected to the extension tube;

\section{After the procedure}

In 2011, Cipriano and Dessote ${ }^{13}$ recommended the use of hospital adhesive tape on the connectors between the extension tube and chest drain to prevent inadvertent disconnection; in 2020, the use of two plastic cable ties with the same purpose was indicated ${ }^{14}$.

Change of water stamp only when indicated and by a properly trained nursing professional, using all indicated PPE.

Keep using the HEPA or HME F filter connected to the patient's collector bottle in order to reduce contamination of the environment, some filters provide an additional resistance of 1 to $2.3 \mathrm{~cm} \mathrm{H}_{2} \mathrm{O}$ to the system ${ }^{14}$ (Figure 3).

One author recently recommended the use of 


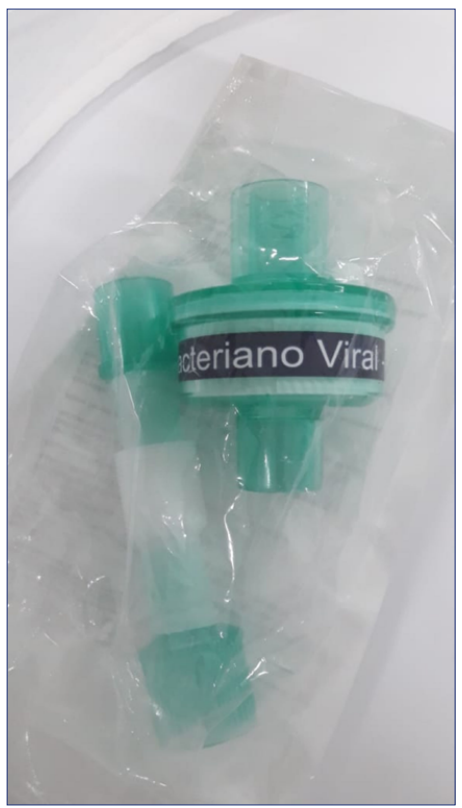

\section{FIGURE 2}

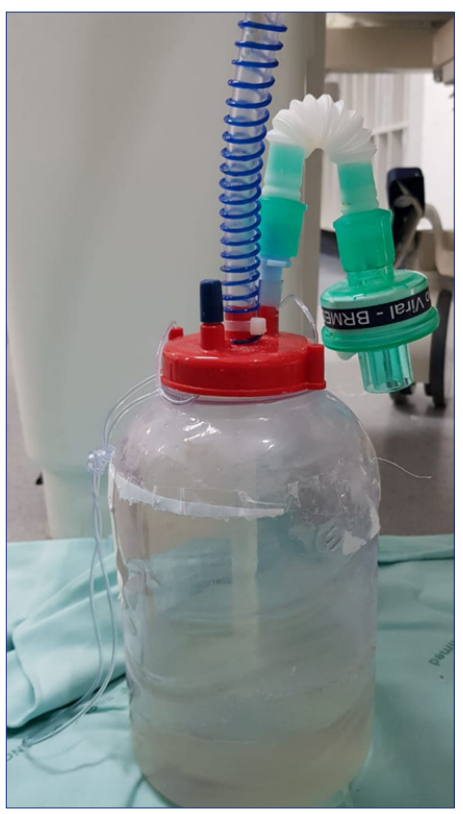

FIGURE 3

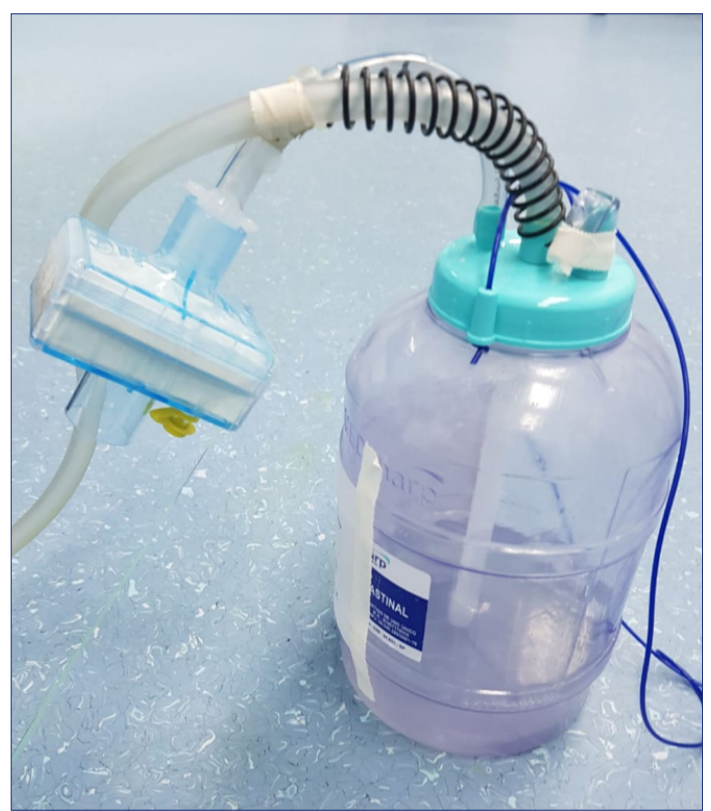

domestic liquid bleach (5.25 to $6.15 \%$ ) on the water seal in a concentration of 1 part to 50 in order to minimize contamination, but we believe that this recommendation still requires further analysis ${ }^{14}$.

Drain removal should be performed with as few people in the room as possible, prior to analgesia, with anesthesia around the drain, making a suture in the drain wound to keep it tightly closed at the end.

\section{DISCUSSION}

Although complications such as pneumothorax affect only $1 \%$ of patients with COVID-19, and pleural effusions with a possible indication for chest tube insertion have been reported in only $5 \%$ of cases, chest drainage continues to be performed in trauma victims and with its classic indications ${ }^{15}$.

Old rules and precautions to avoid contamination such as keeping the drain clamped in its $1 / 3$ distal or having the drain already attached to the extension tube at the time of insertion must be followed thoroughly ${ }^{8}$.

The use of personal protective equipment complete with gloves, cap, N95 or PFF2 mask, face shield, and waterproof apron is essential ${ }^{12}$.

During the patient's convalescence, whether in the ICU or in the wards, all care is necessary during the exchange of the water seals; it is advisable to reinforce the connections with adhesive tape or even with plastic clamps ${ }^{13,14}$.

New approaches, such as the use of a filter with high particle detention power (HEPA), should be considered in order to reduce viral contamination ${ }^{14}$.

Other conducts such as the addition of liquid bleach to the water seal require further analysis of the results before they are indicated ${ }^{14}$.

\section{CONCLUSIONS}

Health officials are under increasing pressure to control the spread of COVID-19, which is a very virulent disease. In this context, many health professionals including doctors, nurses, physiotherapists, and nursing technicians have been contaminated, removed from work, and even lost their lives. Our analysis brought together old rules against contamination with new tactics for professionals who deal with chest drains in order to minimize contamination of the team during the Pandemic.

\section{Author's Contributions}

Bruno José da Costa Medeiros - Data Collection, Writing, Original preparation; Fernando Luíz Westphal - Conceptualization, Writing - Review and Editing, Visualization. 
PALAVRAS-CHAVE: Doenças Transmissíveis. Infecções por Coronavirus. Tubos Torácicos.

\section{REFERENCES}

1. Johns Hopkins University \& Medicine. COVID-19 Dashboard by the Center for Systems Science and Engineering (CSSE) at Johns Hopkins University (JHU). Baltimore: Johns Hopkins University \& Medicine; 2020. [cited 2020 Jun 22]. Available from: https://coronavirus.jhu.edu/map.html

2. World Health Organization. OMS alerta sobre contaminação de profissionais de saúde por COVID-19. Geneva: World Health Organization; 2020. [cited 2020 Mar 19]. Available from: https://news.un.org/pt/ story/2020/02/1704211

3. Conselho Federal de Enfermagem. Profissionais afastados por COVID-19. 2020. Brasília: Conselho Federal de Enfermagem; 2020. [cited 2020 May 26]. Available from: http://www.cofen.gov.br/brasil-tem-30-mortes-naenfermagem-por-COVID-19-e-4-mil-profissionais-afastados_79198.html

4. van Doremalen N, Bushmaker T, Morris DH, Holbrook MG, Gamble A, Williamson BN, et al. Aerosol and surface stability of SARS-CoV-2 as compared with SARS-CoV-1. N Engl ) Med. 2020;382(16):1564-7.

5. Bilkhu R, Viviano A, Saftic I, Bille A. COVID-19: chest drains with air leak: the silent 'super spreader'? CTSNet. 2020. doi.org/10.25373/ctsnet.12089130. v1. [cited 2020 May 26]. Available from: https://ctsnet.figshare.com/ articles/COVID-19_Chest_Drains_With_Air_Leak_The_Silent_Super_ Spreader_/12089130/1

6. Associação Brasileira de Medicina de Emergência - ABRAMEDE. Recomendações para intubação orotraqueal em pacientes portadores de COVID-19. 2020. [cited 2020 May 26]. Available from: http://abramede. com.br/wp-content/uploads/2020/04/Recomendacoes-IOT-FINAL-REVISAO-100420.pdf

7. Akhtar MR, Ricketts $W$, Fotheringham $T$. Use of an antiviral filter attached to a pleural drain bottle to prevent aerosol contamination with SARS-CoV-2. Clin Med (Lond). 2020;20(4):e60-1.
8. Medeiros BIC Westphal FL, Lima LC. Cuidados padronizados em dreno de tórax: técnicas e manejo: técnicas e Manejo. São Paulo: Manole; 2019. p.41-6.

9. American College of Surgeons. ATLS Advanced Trauma Life Support: student course manual. 10 th ed. Chicago: American College of Surgeons; 2018.

10. Lima DS, Ribeiro Junior MF, Vieira-Jr HM, Campos T, Savieiro S. Alternativas para o estabelecimento de via aérea cirúrgica durante a pandemia de COVID-19. Rev Col Bras Cir. 2020;47:e20202549.

11. Schultz P, Morvan JB, Fakhry N, Morinière S, Vergez S, Lacroix C, et al; French Society of Otorhinolaryngology, Head, Neck Surgery (SFORL); French Society of Head, Neck Carcinology (SFCCF). French consensus regarding precautions during tracheostomy and post-tracheostomy care in the context of COVID-19 pandemic. Eur Ann Otorhinolaryngol Head Neck Dis. 2020;137(3):167-9.

12. Center for Disease Control and Prevention. Coronavirus COVID-19. Atlanta: Center for Disease Control and Prevention; 2020. [cited 2020 May 28]. Available from: https://www.cdc.gov/coronavirus/2019-ncov/index.html

13. Cipriano FG, Dessote LU. Drenagem pleural. Medicina (Ribeirão Preto). 2011;44(1):70-8

14. Pieracci FM, Burlew CC, Spaim D, Livingston DH, Bulger EM, Davis KA et al. Tube thoracostomy during the COVID-19 pandemic: guidance and recommendations from the AAST Acute Care Surgery and Critical Care Committees. Trauma Surg Acute Care Open. 2020;5(1):e000498.

15. Chen N, Zhou M, Dong X, Qu J, Gong F, Han Y, et al. Epidemiological and clinical characteristics of 99 cases of 2019 novel coronavirus pneumonia in Wuhan, China: a descriptive study. Lancet. 2020;395(10223):507-13. 